Article

\title{
Can ESG Indices Improve the Enterprises' Stock Market Performance?-An Empirical Study from China
}

\author{
Xiang Deng and Xiang Cheng *(1) \\ School of Economics, Sichuan University, No. 24 South Section 1 Yihuan Road, Chengdu 610064, China \\ * Correspondence: chengxiang@stu.scu.edu.cn or chengxiang_scu@163.com
}

Received: 2 August 2019; Accepted: 30 August 2019; Published: 1 September 2019

\begin{abstract}
Environmental, social responsibility, corporate governance (ESG) are increasingly becoming the consensus of enterprises' development. However, whether the ESG indices of enterprises can improve their performance on stock market is rarely studied. In order to examine the relationship between enterprise's ESG indices and stock market performance, and to further explore the heterogeneity impact of stock market performance on the enterprises' ESG indices in different ownership backgrounds, we conducted an empirical analysis based on China's A-share listed companies. The empirical results show that there is a positive correlation between enterprise's ESG indices and its stock market performance. Further analysis indicates that, the impact of ESG indices on non-state-owned enterprises is greater than that on state-owned enterprises, and the stock market performance of the secondary industry is much more affected by ESG indices than that of the tertiary industry. Finally, from three aspects including information disclosure, policy protection, transformation and upgrading, recommendations are proposed on the future direction of China's ecological civilization construction and sustainable development of enterprises.
\end{abstract}

Keywords: sustainable development; stock market performance; ESG indices

\section{Introduction}

Environmental problems such as environmental pollution, resource depletion, and ecological imbalances have increasingly become global economic and political issues, which are relevant for human survival and social development. A consensus has been reached on the necessity of strengthening environmental protection to achieve sustainable economic and social development. International organizations, government agencies, and academic institutions are exploring various paths to achieve sustainable development strategies, especially with respect to alleviating environmental problems and addressing climate change. Sustainable development, which is defined as "meets the needs of the present without compromising the ability of future generations to meet their own needs" [1], is an inevitable requirement for building a modern economic system and a fundamental strategy for solving pollution problems. Important as it is, there is still a long way to go. And now further work is required on green economy to achieve sustainability [2]. The concept of "green economy" dates back to 1989 [3]. Up to now, the connotation has evolved from the single dimension of "improving the ecological environment" to "one that results in improved human well-being and social equity, while significantly reducing environmental risks and ecological scarcities" according to UNEP [2]. Moreover, green economy together with innovation, coordination, openness, and sharing has become the "five core development concepts" of China in the new era, which is also a consensus choice for global development. It is necessary to reform and improve relevant systems and jointly promote economic development and ecological environment. 
Sustainable development has not only become an essential part of the government's governance and enterprise development, but also been an academic focus [4]. Specific to enterprise development, environmental, social responsibility, corporate governance (ESG) are increasingly becoming a consensus [4-6]. ESG is an extension and enrichment of the concept of green economy, corporate social responsibility, and responsible investment, which also refers to important standards for current international society to measure the level of sustainable development [5]. Institutional investors, asset managers, financial institutions, and other stakeholders are increasingly relying on ESG reports and indices to assess and measure company performance over time as compared to peers [6]. The stakeholder infers that a company with good ESG practices/reputation should be able to perform well when competing in the market $[7,8]$. Evidence also shows that market interest in the transparency of firms' ESG performance and practice is large and growing [9]. As scholars have confirmed, enterprises that seek for ESG development will benefit in terms of reputation, investor attractiveness, employee satisfaction, and innovation [10-12], which may have a positive effect on the stock market performance [13-15]. Investors are also increasingly convinced that by combining ESG with investment processes, they can fully realize long-term benefits [6]. Besides, good corporate governance and sustainable development can help create long-term benefits for shareholders [16]. As Henriksson et al. [17] studied, companies that have better ESG scores are more likely to have lower equity capital costs and higher credit ratings. The empirical results also show that companies with outstanding performance in any of the three fields, including environmental, social responsibility, and corporate governance, can reduce corporate financing costs [18-20]. Thus, enhancing ESG aspects will lead to lower corporate financing costs $[18,20]$.

Though the predominant academic finding is a positive association between ESG and financial performance, there is still not a univocal consensus. Some results are ambiguous, inconclusive, or contradictory [21-23]. It still remains a concern for some scholars that if companies pay too much attention to ESG, they will adopt a series of standards when making investment decisions, which may limit the scope of investment and lower the earnings of enterprises [24,25]. Meanwhile, a large body of literature indicates that the effects of policies are influenced by the heterogeneity of agents, and enterprises with different ownership backgrounds and industrial backgrounds will response differently to policies [26-28]. But few people have studied the market's response to the ESG indices of enterprises and they have also ignored the impacts on heterogeneity of enterprises.

In order to study the relationship between ESG indices and the stock market performance, and further examine the heterogeneous impact of ESG indices on the stock market performance against different ownership backgrounds and industrial backgrounds, we use quarterly data from China's A-share listed companies from 2011Q1 to 2019Q1 to conduct empirical analysis. Besides, the fixed effect (FE) model, which refers to a regression model in which the group means are fixed (non-random) as opposed to a random effects model in which the group means are a random sample from a population [29], and the generalized method of moments (GMM) model, which is widely used in a generic method for estimating parameters in statistical models [30,31], are also applied to study the relationship between ESG indices and stock market performance.

The highlights of this paper lie in three points. First, the research focus of this paper is rather novel. When most of the existing research focuses on the construction of ESG indices, the impact of ESG indices on the financial status of enterprises, and the factors that influence ESG indices, this paper, however, attempts to examine the relationship between enterprise's ESG indices and stock market performance and further explore the heterogeneity impact of stock market performance on the enterprises' ESG indices in different ownership backgrounds. Second, in addition to the analysis of the panel data model which is commonly used in the literature, this paper also analyzes the relationship between ESG indices of the enterprise and the stock market performance through the difference in difference (DID) test and dynamic panel model, leading to a more stable result. Third, this paper focuses on the market's response to the ESG indices of enterprises and whether enterprises can achieve a "win-win" situation on obtaining profits and living up to the government's expectation about sustainable development. 
Hopefully, it may help to provide theoretical reference for the new era to implement the sustainable development policy.

The remainder of this paper is organized as follows. Section 2 describes the basic model, main variables, and empirical data. In Section 3, we report the empirical results and conduct a further analysis about heterogeneity. Section 4 gives conclusions and policy recommendations.

\section{Model and Data}

In this section, a description about the basic model, main variables, and empirical data will be given. By summarizing the models in literatures on enterprise stock market performance [32-34], we construct an empirical model to examine enterprises ESG indices and their stock market performance via the FE model. In addition to the analysis of the panel data model commonly used in the literature, this study also analyzes the relationship between the ESG indices and stock market performance through the DID test and the GMM model, which makes the result more stable than before.

In order to study the impact of ESG indices on the performance of the enterprise's stock market, we establish the following models based on Sardo and Serrasqueiro [32]; Zhang et al. [33]; Ge [34] to carry out the empirical analysis:

$$
\begin{gathered}
E P S_{i, t}=\beta E S G_{i, t}+\delta X_{i, t}+\alpha_{i}+\gamma_{t}+\mu_{i, t} \\
E P S_{i, t}=\lambda E P S_{i, t-1}+\beta E S G_{i, t}+\delta X_{i, t}+\alpha_{i}+\gamma_{t}+\mu_{i, t}
\end{gathered}
$$

We use earnings per share (EPS) as an indicator of corporate stock market performance. In the above equations, $E P S_{i, t}$ is the stock market performance of the enterprise $i$-th in the period $t$ and is also the core dependent variable of this study. There are mainly two methods that previous scholars have applied to measure the stock market performance: event study method [35-37] and financial indicator method [38,39]. An event study is a statistical method to assess the impact of an event on the value of a firm. Its basis is to find the abnormal return attributable to the event being studied by adjusting for the return that stems from the price fluctuation of the market as a whole [40]. The financial indicator method, however, is to use a single financial indicator or establish a financial indicator evaluation system to assess the company's operating performance [33]. Many scholars have claimed that because of the defects of China's capital market system itself, the stock price is easy to be manipulated [33,34]. Meanwhile, the company's sustainable development is ongoing. Hence, it is less reasonable to use extreme practices to assess the company's development. As a result, the event research method is not applicable in this study. Therefore, we use the financial indicator method to select EPS [41-43] as an indicator of stock market performance. EPS is equal to the company's current net profit divided by the number of ordinary shares issued in the current period. In general, the higher the ratio, the more profit it creates and the better the stock market performance. This study selects the 2011Q1 to 2019Q1 quarter EPS data published in the WIND database [44] and processes the data accordingly.

$E S G_{i, t}$ is the ESG indices of enterprise $i$ in period $t$. There are some ESG rating systems in the world, such as the Dow Jones Sustainability Index, MSCI ESG Research, etc. [6]. There are, however, very few companies which are assessed by those rating systems in China. Moreover, less rights are given to us to get relevant rating data. So, we collect ESG indices data from ESG rating reports issued by two professional Chinese rating agencies. All the ESG indices data can be obtained through the WIND database. This article takes the quarterly data from 2015Q2 to 2019Q1 as a sample.

The first is the SynTao Green Finance ESG rating index (ST-ESG) [45]. As a leading consultancy providing professional services in green finance and responsible investment in China. SynTao Green Finance has developed the ESG rating system of Chinese listed companies by combining international standards with the current situations of information disclosure in Chinese companies. By collecting and quantifying the company's ESG information, it finally transformed ESG information into a sustainable score system applicable for investors. The ST-ESG is a three-level indicator system, with the first level including the three-dimensional indicators of environment, society, and corporate governance, the 
second level being 13 categories of indicators under environmental, social, and corporate governance and the third level covering more than 200 indicators which are derived from more than 1000 data points.

The second is the China Alliance of Social Value Investment ESG rating index (SV-ESG) [46]. As the first licensed international non-profit organization, China Alliance of Social Value Investment specializes in building the ecosystem of sustainable finance in China. The ecosystem is constructed by developing models to assess social value and establishing a platform that connects sustainable investors with investees as well as raising public awareness of the total value in terms of ESG. Social value, which includes both righteousness and benefit, refers to the economic, social, and environmental realization of the organization for a more sustainable future with higher quality, efficiency, and fairness, which can be achieved by investing in innovative production technologies, operational models, and management mechanisms. The social value assessment model of listed companies consists of two parts: "screening sub-model" and "scoring sub-model." The former one is a negative assessment of social value that will select qualified listed companies, after which the "scoring sub-model" will quantify the contribution of social value. The "scoring sub-model" includes three primary indicators (targets, methods, and benefits), 9 secondary indicators, 27 third-level indicators, and 55 four-level indicators.

To avoid the subjectivity of the classification, we quantify the ESG rating in two ways. The first way is that we sort ESG indexes from low to high according to the sample level, the lowest level is counted as 1 , and the rank is changed by 1 . Another way is that according to ST-ESG rating and SV-ESG rating, the ESG indexes are divided into five levels, the lowest level is recorded as 1, and the highest level is recorded as 5. Therefore, we get four ESG indices marked as ESG-1, ESG-2, ESG-3, and ESG-4, and Table 1 shows the ways of measuring ESG indices of enterprises.

Table 1. Ways of measuring environmental, social responsibility, corporate governance (ESG) indices of enterprises.

\begin{tabular}{ccl}
\hline Variable & Source of Indicators & \multicolumn{1}{c}{ Approach } \\
\hline ESG-1 & ST-ESG & $\begin{array}{l}\text { Sort from low to high according to the sample level, the lowest } \\
\text { level is counted as 1, and the rank is changed by 1. } \\
\text { According to ST-ESG, the ESG index is divided into five levels, } \\
\text { the lowest level is recorded as 1, and the highest level is } \\
\text { recorded as 5. } \\
\text { Sort from low to high according to the sample level, the lowest } \\
\text { level is counted as 1, and the rank is changed by 1. } \\
\text { According to SV-ESG, the ESG index is divided into five levels, } \\
\text { the lowest level is recorded as 1, and the highest level is } \\
\text { recorded as 5. }\end{array}$ \\
ST-ESG & SV-ESG &
\end{tabular}

$X_{i, t}$ is the control vector. In order to overcome the problem of missing variables as much as possible, this paper selects the following controlled variables based on the previous research: total return on assets (ROA) [42], number of independent directors (LL) [47], shareholding ratio of the largest shareholder (FH) [38,39], cash shares to total assets (CA) [42], corporate sales gross profit (SFEE) [47], asset-liability ratio (ALR) [47,48], government subsidies to main business income (GSZS) [48], and executive compensation (Salary) [49]. The raw data of the above variables are derived from the WIND database from 2011Q1 to 2019Q1. And the quarterly data are obtained by processing the sample data. Table 2 is a descriptive statistic of the main regression variables.

In Equations (1) and (2), $\beta$ and $\lambda$ are the coefficients of $S L_{i, t}$ and $E P S_{i, t-1}$ respectively, and $\delta$ is the coefficient matrix of $X_{i, t} ; \alpha_{i}$ and $\gamma_{t}$ are the fixed effects respectively of individuals and years; $\mu_{i, t}$ means a term of random disturbance. Equation (1) considers the contemporaneous effects between variables, while Equation (2) considers the lag period effects between variables, that is, $S L_{i, t-1}$ and $X_{i, t-1}$ affect $E P S_{i, t}$ by affecting $E P S_{i, t-1}$. All regression analyses in this paper have individual fixed effects and year fixed effects controlled, and robust standard error regression is applied to overcome the potential heteroscedasticity problems. Therefore, the validation of the analysis is ensured, and it can also help to alleviate potential biases in estimators and the corresponding standard errors [31,32]. In terms of model selection, for the panel data of listed companies, the Hausman test is performed on all benchmark 
regressions, and the test results reject the null hypothesis of the random effects model, so we use the FE model for benchmark test with Equation (1). At the same time, in order to ensure the reliability of the results, we also take the lagged value of the enterprise's stock market performance $\left(E P S_{i, t-1}\right)$ into consideration and further apply the processing method of dynamic panel data in the benchmark model. Besides, the GMM method is also used to test the robustness of the results with the Equation (2). It is helpful to propose such approach because (i) it reduces the impact of all time-invariant (fixed effects) omitted and included variables and (ii) it mitigates dynamic endogeneity problems.

Table 2. Statistics of the regression variables.

\begin{tabular}{cccccc}
\hline Variables & Obs. & Mean & Std. Dev. & Min & Max \\
\hline EPS & 54,392 & 0.258 & 0.527 & -15.540 & 28.020 \\
ESG-1 & 5864 & 2.991 & 0.991 & 1.000 & 6.000 \\
ESG-2 & 5864 & 3.037 & 0.354 & 1.000 & 4.000 \\
ESG-3 & 3763 & 8.255 & 2.968 & 1.000 & 17.000 \\
ESG-4 & 3763 & 3.413 & 0.641 & 1.000 & 5.000 \\
ROA & 49,534 & 1.480 & 4.104 & -190.002 & 136.376 \\
LL & 57,001 & 0.373 & 0.131 & 0.000 & 4.000 \\
FH & 53,896 & 33.995 & 15.833 & 0.196 & 105.144 \\
CA & 52,251 & 0.001 & 0.003 & 0.000 & 0.249 \\
SFEE & 54,449 & 29.983 & 45.604 & -7442.231 & 103.898 \\
ALR & 54,428 & 42.865 & 35.595 & 0.438 & 4308.696 \\
GSZS & 35,038 & 0.019 & 3.713 & -475.387 & 58.890 \\
Salary & 49,325 & 1.692 & 1.984 & 0.035 & 42.213 \\
\hline
\end{tabular}

\section{Empirical Analysis}

\subsection{DID Test}

In order to verify whether the ESG indices signals have an impact on the stock market performance of enterprises, this paper uses the DID model. The dependent variable is the stock market performance (EPS) of the enterprise, the dummy variable of the experimental group is treated (treated $=1$ indicates that the company has ESG indices; treated $=0$ indicates the opposite situation), and the dummy variable in the experiment is time (time $=1$ is when the rating signal appears. For the ST-ESG rating, time $=1$ means the first and the following quarters of 2016 and the follows; for the SV-ESG rating, time $=1$ means the second the following quarters of 2016 and the follows). Table 3 shows the results of the DID test. It can be seen that the ESG indices signal is positively related to the stock market performance of the enterprise.

Table 3. Difference in difference (DID) test results.

\begin{tabular}{ccccc}
\hline & $E S G-1$ & $E S G-2$ & $E S G-3$ & ESG-4 \\
\hline \multirow{2}{*}{ time } & 0.000440 & 0.000440 & $0.0208^{* * *}$ & $0.0208^{* * *}$ \\
& $(0.00345)$ & $(0.00345)$ & $(0.00346)$ & $(0.00346)$ \\
treated & $0.200^{* * *}$ & $0.200^{* * *}$ & $0.203^{* * *}$ & $0.203^{* * *}$ \\
& $(0.00587)$ & $(0.00587)$ & $(0.00594)$ & $(0.00594)$ \\
diff & $0.0281^{* * *}$ & $0.0281^{* * *}$ & $0.0605^{* * *}$ & $0.0605^{* * *}$ \\
& $(0.00927)$ & $(0.00927)$ & $(0.00978)$ & $(0.00978)$ \\
\hline \multirow{2}{*}{ Cons. } & $0.235^{* * *}$ & $0.235^{* * *}$ & $0.228^{* * *}$ & $0.228^{* * *}$ \\
Obs. & $(0.00228)$ & $(0.00228)$ & $(0.00220)$ & $(0.00220)$ \\
$R^{2}$ & 96,310 & 96,310 & 96,310 & 96,310 \\
indicate a notable level of significance at 1\%, and the values in parentheses are robust standard errors.
\end{tabular}

\subsection{Benchmark Regression Analysis}

Based on the results of the test in Table 3, this paper applies the FE model of static panel data and the GMM model of dynamic panel to perform benchmark regression. Besides, the robust standard error 
is applied to overcome the potential heteroscedasticity problem, and at the same time ESG-1, ESG-2, and ESG-3, ESG-4 (as described in Table 1) are used to measure the ESG indices of the enterprise. To further verify the validity of the results, we used the ratio of the earnings before interest and tax (EBIT) and the number of A shares in the company as an indicator (EBITPS) to measure the performance of the company's stock market and conducted a robustness test. Although the regression results were not as good as the results of EPS as a proxy variable, the main conclusions did not change. Please go to Appendix A.

Columns (1)-(4) of Table 4 report the regression results of the static panel FE model. The results show that the ESG indices of the enterprise have a significantly positive effect on its stock market performance. And it is also notable under different ESG indices proxy variables, indicating robustness of the results. Besides, the results also show that coefficients of ESG indices of (1) and (2) are correspondingly higher than that of (3) and (4), which suggests that the ESG indices under the ST-ESG rating system is more representative. In addition, the regression results of the controlled variables are basically in line with the expectations. Among them, the higher the ROA, SFEE, and ALR, the better the stock market performance of the company. This is because these indicators can reflect the company's ability to gain profits to a certain extent, thus the stock market performance can be recognized by investors. In contrast, the shareholding ratio of the largest shareholder, FH, will have a notable negative impact on the stock market performance of the company. This is because the higher the $\mathrm{FH}$, the more investors will believe that the decision-making power of the company is concentrated in the hands of a few people, who might make decisions arbitrarily and even have wrong choices, leading to the decline of the stock market performance.

Table 4. Impact of ESG indices on the stock market performance: benchmark regression.

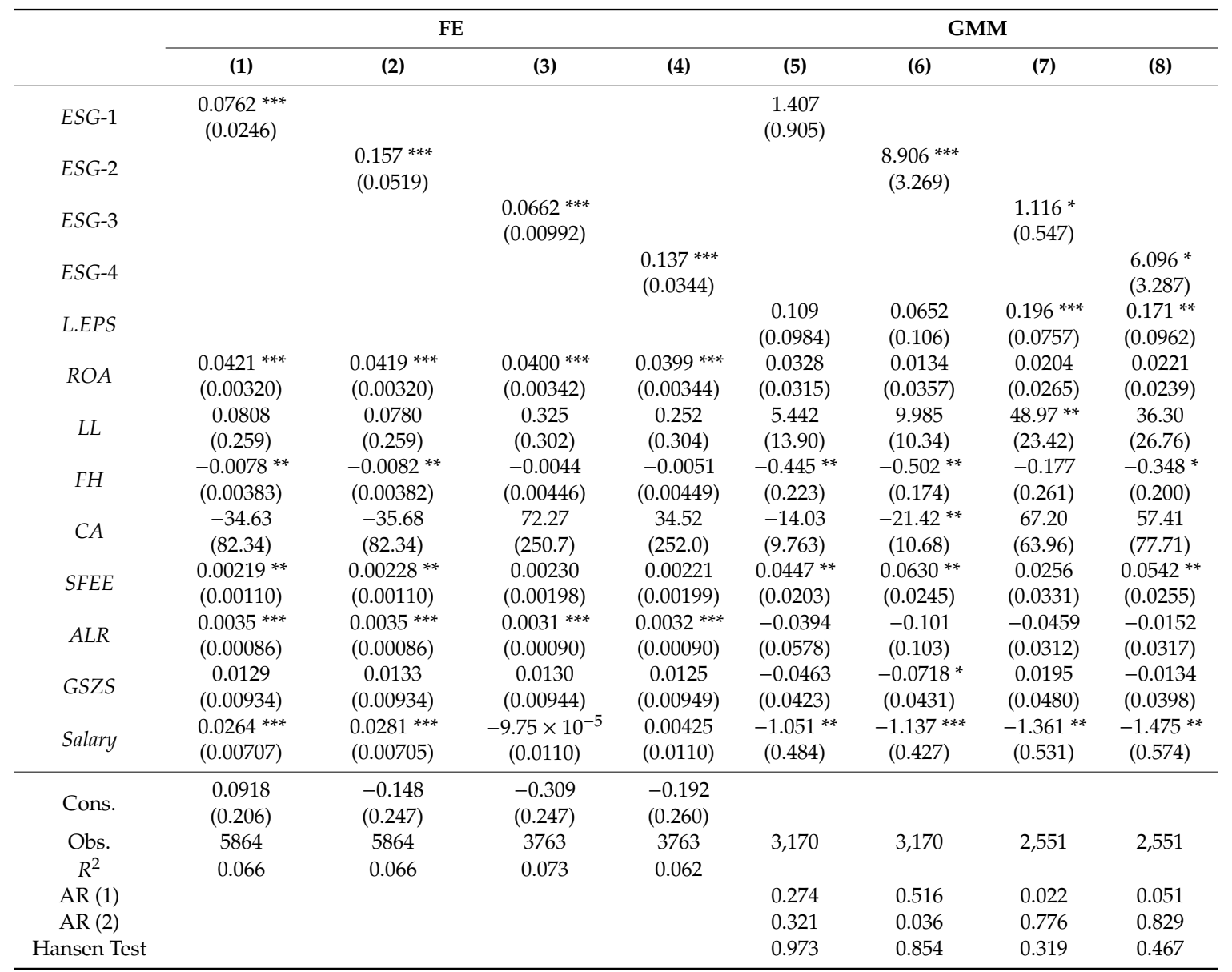

Note: ***,*** indicate a notable level of significance at respectively $10 \%, 5 \%$, and $1 \%$, and the values in parentheses are robust standard errors. 
Columns (5)-(8) in Table 4 are the regression results of the dynamic panel GMM model. The results also show that the ST-ESG rating has a greater impact on the company's stock market performance. Both ST-ESG and SV-ESG rating, however, will have a significantly positive impact on the company's stock market performance, which suggests that the market attaches great importance to the ESG indices of the enterprise. In addition, the previous performance of the market will notably affect its current performance, which is due to the fact that investors' assessments of the company will typically focus only on its historical financial information. Therefore, the favorable financial information of the company in the past often gives positive signals to the market. Besides, both the number of independent directors and the shareholding ratio of the largest shareholder of the company play important roles in its market performance, which suggests that the market attaches great importance to whether the enterprise can conduct objective and independent business decision-making. If there are more independent directors and a lower shareholding ratio of the largest shareholder in the company, then the decision of the board of directors can be fairer, showing less individual will of the company executives in business decision-making. Similarly, the gross profit of the company's sales will directly affect its market performance.

\subsection{Analysis of Heterogeneity}

Considering that the difference of ownership backgrounds and industries may bring about disparities to the degree of being affected by ESG indices, this section attempts to explore the possible heterogeneous impact of the ESG indices by dividing ownership backgrounds and industries into different types.

Based on the backgrounds of the major shareholders or actual controllers, this paper divides enterprises into state-owned enterprises, foreign-funded enterprises, private enterprises, collective enterprises, and public enterprises. Because of the limited data, the regression results of foreign-funded enterprises are remarkably collinear. Therefore, it is better to exclude those foreign enterprises for a more scientific research. Among them, Chinese state-owned enterprises are divided into central state-owned enterprises and local state-owned enterprises. The former one refers to enterprises whose major shareholders or actual controllers belong to the State-owned Assets Supervision and Administration Commission (SASAC), central state organs or central state-owned enterprises or institutions. The local state-owned enterprises refer to those enterprises whose major shareholders or actual controllers are from the local SASAC, local governments, departments or local state-owned enterprises or institutions. As for private enterprises, they are non-public companies, including individual and private ones, which are characterized by the absence of state-owned capital and non-state holding. Collective enterprises refer to the collective economic system which is based on working people's collective ownership of means of production, and whose major way of distribution is in the form of labor (some enterprises implement the distribution that combines labor and capital). Public enterprises are companies without actual controllers. For the convenience of the later research, this paper divides the sample enterprises into two categories, namely, state-owned enterprises (including central state-owned enterprises and local state-owned enterprises) and non-state-owned enterprises (private enterprises, collective enterprises and public enterprises).

Table 5 reports the results of how the ESG indices will affect the stock market performance of the state-owned enterprises. From its regression coefficient, we can see that the ESG indices of state-owned enterprises will significantly affect the stock market performance. The degree of impact, however, is less than the average level of being affected (compared with the corresponding coefficient in Table 4). The main reasons are as follows. Primarily, being an important part of building an ecological civilization, pursing sustainable development is a policy proposed by the central government to be implemented in the future. Besides, state-owned enterprises are in a dominant position in the national economy, receiving more attention from society. Therefore, there is much more social responsibility and burden coming from the policy for those state-owned enterprises than non-state-owned enterprises [50]. Moreover, state-owned enterprises are guaranteed by government funds, which is more stable than 
non-state-owned enterprises. Even if ESG performs poorly, market investors will still favor state-owned enterprises, so the impact of sustainable development on state-owned enterprises is lower than the market average.

Table 5. Impact of ESG indices on the stock market performance of state-owned enterprises.

\begin{tabular}{|c|c|c|c|c|c|c|c|c|}
\hline & \multicolumn{4}{|c|}{$\mathrm{FE}$} & \multicolumn{4}{|c|}{ GMM } \\
\hline & (1) & (2) & (3) & (4) & (5) & (6) & (7) & (8) \\
\hline ESG-1 & $\begin{array}{l}0.041 * \\
(0.022)\end{array}$ & & & & $\begin{array}{c}1.114^{* * *} \\
(0.416)\end{array}$ & & & \\
\hline$E S G-2$ & & $\begin{array}{l}0.00030 \\
(0.0490)\end{array}$ & & & & $\begin{array}{c}1.267 \\
(2.056)\end{array}$ & & \\
\hline ESG-3 & & & $\begin{array}{l}0.077^{* * *} \\
(0.0109)\end{array}$ & & & & $\begin{array}{l}0.345^{* *} \\
(0.135)\end{array}$ & \\
\hline ESG-4 & & & & $\begin{array}{c}0.17^{* * *} \\
(0.0380)\end{array}$ & & & & $\begin{array}{c}1.879^{* * *} \\
(0.725)\end{array}$ \\
\hline Obs. & 1806 & 1806 & 1461 & 1461 & 1626 & 1626 & 1302 & 1302 \\
\hline$R^{2}$ & 0.138 & 0.136 & 0.172 & 0.153 & & & & \\
\hline AR (1) & & & & & 0.014 & 0.061 & 0.150 & 0.043 \\
\hline AR (2) & & & & & 0.503 & 0.746 & 0.820 & 0.859 \\
\hline Hansen Test & & & & & 0.025 & 0.005 & 0.011 & 0.024 \\
\hline
\end{tabular}

Note: ${ }^{*}, * * * * *$ indicate a notable level of significance at respectively $10 \%, 5 \%$, and $1 \%$, and the values in parentheses are robust standard errors. Because of limited space, the regression results of the controlled variables are not reported. If you are interested, please contact the author for more details. The table below is the same.

Table 6 reports the results of the impact of ESG indices on stock market performance of non-state-owned enterprises. The results show that the ESG indices of non-state-owned enterprises will significantly affect the market performance of enterprises. Surpassing the average level (compared with the corresponding coefficient in Table 4), the degree of being influenced for private enterprises is also higher than that of state-owned enterprises (compared with the corresponding coefficients in Table 5). For the private sector, it is more market-oriented, with the stock market value being strongly correlated with the expectations of shareholders. When the performance of ESGs of non-state-owned enterprises is reduced, shareholders are pessimistic about their overall performance, leading to a reduction in stock market value.

Table 6. Impact of ESG indices on the stock market performance of non-state-owned enterprises.

\begin{tabular}{|c|c|c|c|c|c|c|c|c|}
\hline & \multicolumn{4}{|c|}{ FE } & \multicolumn{4}{|c|}{ GMM } \\
\hline & (1) & (2) & (3) & (4) & (5) & (6) & (7) & (8) \\
\hline$E S G-1$ & $\begin{array}{l}0.118^{* *} \\
(0.0492)\end{array}$ & & & & $\begin{array}{l}1.767^{*} \\
(0.965)\end{array}$ & & & \\
\hline$E S G-2$ & & $\begin{array}{l}0.270 * * * \\
(0.0949)\end{array}$ & & & & $\begin{array}{l}5.260 * \\
(2.945)\end{array}$ & & \\
\hline ESG-3 & & & $\begin{array}{c}0.0709 * * * \\
(0.0169)\end{array}$ & & & & $\begin{array}{l}1.537^{*} \\
(0.849)\end{array}$ & \\
\hline$E S G-4$ & & & & $\begin{array}{l}0.135 * * \\
(0.0570)\end{array}$ & & & & $\begin{array}{c}3.905 \\
(3.248)\end{array}$ \\
\hline Obs. & 1648 & 1648 & 1354 & 1354 & 1467 & 1467 & 1187 & 1187 \\
\hline$R^{2}$ & 0.052 & 0.053 & 0.053 & 0.044 & & & & \\
\hline AR (1) & & & & & 0.132 & 0.153 & 0.012 & 0.051 \\
\hline $\mathrm{AR}(2)$ & & & & & 0.112 & 0.146 & 0.700 & 0.891 \\
\hline Hansen Test & & & & & 0.168 & 0.107 & 0.088 & 0.197 \\
\hline
\end{tabular}

Note: ${ }^{* * *}, * * *$ indicate a notable level of significance at respectively $10 \%, 5 \%$, and $1 \%$, and the values in parentheses are robust standard errors.

Tables 7 and 8 respectively examine the impact of ESG indices on the stock market performance in different industries. According to the National Economic Industry Classification (GB/T 4754-2011), the sample enterprises can be divided into primary industry, secondary industry, and tertiary industry. 
Since there are fewer rating data for listed companies in the primary industry in both ST-ESG and SV-ESG rating agency, we exclude the sample of enterprises in the primary industry and attempt to analyze the listed companies in the secondary and tertiary industries to avoid false regression and result bias.

Table 7. Impact of ESG indices on the stock market performance of secondary industry enterprises.

\begin{tabular}{|c|c|c|c|c|c|c|c|c|}
\hline & \multicolumn{4}{|c|}{ FE } & \multicolumn{4}{|c|}{ GMM } \\
\hline & (1) & (2) & (3) & (4) & (5) & (6) & (7) & (8) \\
\hline ESG-1 & $\begin{array}{l}0.112 * * * \\
(0.0362)\end{array}$ & & & & $\begin{array}{l}1.959^{* *} \\
(0.900)\end{array}$ & & & \\
\hline$E S G-2$ & & $\begin{array}{l}0.263^{* * *} \\
(0.0741)\end{array}$ & & & & $\begin{array}{c}8.788^{* * *} \\
(2.613)\end{array}$ & & \\
\hline$E S G-3$ & & & $\begin{array}{c}0.0814^{* * *} \\
(0.0148)\end{array}$ & & & & $\begin{array}{l}1.157^{*} \\
(0.585)\end{array}$ & \\
\hline$E S G-4$ & & & & $\begin{array}{l}0.205^{* * *} \\
(0.0509)\end{array}$ & & & & $\begin{array}{l}6.082 * * \\
(3.053)\end{array}$ \\
\hline Obs. & 2286 & 2286 & 1825 & 1825 & 2038 & 2038 & 1602 & 1602 \\
\hline$R^{2}$ & 0.048 & 0.050 & 0.054 & 0.046 & & & & \\
\hline $\mathrm{AR}(1)$ & & & & & 0.306 & 0.682 & 0.026 & 0.072 \\
\hline AR (2) & & & & & 0.388 & 0.175 & 0.552 & 0.776 \\
\hline Hansen Test & & & & & 0.175 & 0.038 & 0.175 & 0.156 \\
\hline
\end{tabular}

Note: ${ }^{*}, * * * * *$ indicate a notable level of significance at respectively $10 \%, 5 \%$, and $1 \%$, and the values in parentheses are robust standard errors.

Table 8. Impact of ESG indices on the stock market performance of tertiary industry enterprises.

\begin{tabular}{|c|c|c|c|c|c|c|c|c|}
\hline & \multicolumn{4}{|c|}{ FE } & \multicolumn{4}{|c|}{ GMM } \\
\hline & (1) & (2) & (3) & (4) & (5) & (6) & (7) & (8) \\
\hline$E S G-1$ & $\begin{array}{c}0.0336 \\
(0.0233)\end{array}$ & & & & $\begin{array}{c}0.363 \\
(0.352)\end{array}$ & & & \\
\hline$E S G-2$ & & $\begin{array}{l}-0.0163 \\
(0.0513)\end{array}$ & & & & $\begin{array}{c}0.540 \\
(0.978)\end{array}$ & & \\
\hline$E S G-3$ & & & $\begin{array}{l}0.0452 * * * \\
(0.00897)\end{array}$ & & & & $\begin{array}{c}0.475 \\
(0.299)\end{array}$ & \\
\hline$E S G-4$ & & & & $\begin{array}{c}0.0292 \\
(0.0318)\end{array}$ & & & & $\begin{array}{l}-0.054 \\
(0.397)\end{array}$ \\
\hline Obs. & 1171 & 1171 & 995 & 995 & 1053 & 1053 & 887 & 887 \\
\hline$R^{2}$ & 0.249 & 0.247 & 0.265 & 0.244 & & & & \\
\hline AR (1) & & & & & 0.245 & 0.422 & 0.174 & 0.597 \\
\hline AR (2) & & & & & 0.009 & 0.058 & 0.160 & 0.109 \\
\hline Hansen Test & & & & & 0.111 & 0.106 & 0.086 & 0.216 \\
\hline
\end{tabular}

Note: ${ }^{* * *}$ indicate a notable level of significance at $1 \%$, and the values in parentheses are robust standard errors.

Comparing the results of Tables 7 and 8, we can see that the impact of ESG indices on the secondary industry is significantly stronger and more stable than that of the tertiary industry. The secondary industry is mainly about processing and manufacturing while the tertiary industry is mainly service industry. Therefore, it is reasonable to say that enterprises in the secondary industry are more likely to pollute the environment than the companies in the tertiary industry will do. When enterprises in the secondary industry actively invest more money in environmental protection projects such as the research and development of environmental technology, clean and green production, attempting to improve their social responsibility and management ability, then a series of positive outcomes will be generated. For example, it may bring an increase in product market share as well as a reduction in the cost of products and pollution control, and it can also contribute to setting up a green image for the company and improve its reputation, all of which will increase the market value of the company. The above conclusions remain robust by replacing sustainable development indicators and adopting different regression models. 


\section{Conclusions and Policy Recommendations}

This study takes China's A-share listed companies as a sample and studies the relationship between the ESG indices and the stock market performance of enterprises. By conducting the DID test, and applying the FE model of the static panel as well as the GMM model of the dynamic panel to estimate the sample, we found that the improvement of the ESG indices of enterprises can notably enhance their stock market performance, and at the same time achieve a "win-win" situation between social value and business development. Further heterogeneity analysis revealed that the influence of ESG indices on non-state-owned enterprises is greater than that on state-owned enterprises. Besides, compared with enterprises in the tertiary industry, companies in secondary industry are much more affected by the ESG indices on their market value.

Protecting environment and establishing a sustainable governance system in the company have increasingly become key factors that must be considered in business operations. In order to better implement the sustainable development policy and further promote the construction of China's ecological civilization, three police recommendations based on the above research conclusions are put forward.

First of all, the government should improve the information disclosure system related to sustainable development of enterprises and reasonably guide market expectations. Although the world is not hurtling toward a green revolution, sustainable development is an inevitable choice in the future. Hence, enterprises with good performance of ESG indices and outstanding achievements in sustainable development should be rewarded by concessions from government subsidies and taxation. As a result, those enterprises will be encouraged to continuously improve their environmental performance and develop their information disclosure system, thereby attracting more funds that favor green themes and thus creating a virtuous circle. Besides, in order to ensure fairly objective and authoritative rating results, the government ought to establish a supervision mechanism for the sustainable development rating. Relevant functional departments such as the government should set up an information screening system, which could contribute to a strict and serious penalization system against the information fraud, data manipulation, and other behaviors that disrupt the market order. Moreover, those functional sections should also share data with environmental protection departments to ensure the authority of rating results.

Second, when providing policy guarantees, the government should take the variance and difference of certain enterprises into consideration. Non-state-owned enterprises with higher marketization levels are more easily to be affected by the level of sustainable development. Thus, they should be encouraged to implement sustainable development policies with corresponding subsidies and tax incentives provided by the government. By doing so, the burden of cost shouldered by those enterprises when conducting sustainable development can be compensated to some extent, thereby inspiring those non-state-owned enterprises for a sustainable development and the realization of sustainable national economy. It is also imperative for those enterprises to properly phase out high-pollution and high-consumption enterprises from all industries and promote the transformation and upgrading of the secondary industry. For enterprises that cause severe pollution, it is essential that they must increase investment in environmental protection so as to encourage the introduction and application of green technologies. Besides, the improvement of enterprises' social responsibility and management ability is also required, which contributes to establishing their green image for a better reputation. Moreover, the carrying capacity of environment should be reasonably assessed. Hence it is an obligation that enterprises with large resource consumption and high pollution level must be rectified or eliminated.

Finally, entrepreneurs and investors should increase their sense of social responsibility. As a global development initiative, the Belt \& Road [51] is increasingly recognized worldwide. However, the economic development of most countries and regions along the Belt \& Road is still relatively unsustainable, with a much higher level of energy consumption and carbon emission than the world average. The integration of the green investment concept into the Belt \& Road has reached consensus among many governments and financial institutions. Recently, 27 global institutions sign up to green 
investment principles for the Belt \& Road. Although the green investment of Belt \& Road has a long way to go, it will effectively promote new infrastructure projects to achieve a win-win situation with human, ecological, and economic benefits. Therefore, entrepreneurs and investors should strengthen their sense of social responsibility instead of only focusing on short-term profits when assessing investment projects and making-decisions. Only in this way can we meet the needs of the present without compromising the interests of the future generations.

Author Contributions: D.X. conceived the study and proposed the methodology; C.X. was responsible for data curation and draft.

Funding: This research was funded by the National Natural Science Foundation of China, Nos. 71742004, 71673194, 71473169 for D.X. and the Graduate Student's Research and Innovation Fund of Sichuan University, No.2018YJSY001 for C.X. The APC was funded by Sichuan University.

Conflicts of Interest: The authors declare no conflict of interest.

\section{Appendix A}

Table A1. Impact of ESG indices on the stock market performance: based on EBITPS.

\begin{tabular}{|c|c|c|c|c|c|c|c|c|}
\hline & \multicolumn{4}{|c|}{ FE } & \multicolumn{4}{|c|}{ GMM } \\
\hline & (1) & (2) & (3) & (4) & (5) & (6) & (7) & (8) \\
\hline ESG-1 & $\begin{array}{c}0.0965^{* * *} \\
(0.0272)\end{array}$ & & & & $\begin{array}{l}1.682 * * \\
(0.720)\end{array}$ & & & \\
\hline ESG-2 & & $\begin{array}{c}0.0414 \\
(0.0575)\end{array}$ & & & & $\begin{array}{l}2.737^{*} \\
(1.590)\end{array}$ & & \\
\hline ESG-3 & & & $\begin{array}{c}0.0469 * * * \\
(0.0116)\end{array}$ & & & & $\begin{array}{c}0.178 \\
(0.292)\end{array}$ & \\
\hline$E S G-4$ & & & & $\begin{array}{l}0.0757^{*} \\
(0.0395)\end{array}$ & & & & $\begin{array}{l}-1.873 \\
(1.439)\end{array}$ \\
\hline Obs. & 3455 & 3455 & 2815 & 2815 & 2837 & 2837 & 2477 & 477 \\
\hline$R^{2}$ & 0.010 & 0.006 & 0.011 & 0.006 & & & & \\
\hline AR (1) & & & & & 0.140 & 0.158 & 0.152 & 0.188 \\
\hline AR (2) & & & & & 0.598 & 0.494 & 0.986 & 0.820 \\
\hline Hansen Test & & & & & 0.435 & 0.473 & 0.278 & 0.365 \\
\hline
\end{tabular}

Note: ${ }^{*}, * * * *$ indicate a notable level of significance at respectively $10 \%, 5 \%$, and $1 \%$, and the values in parentheses are robust standard errors. Because of limited space, the regression results of the controlled variables are not reported. If you are interested, please contact the author for more details.

\section{References}

1. World Commission on Environment and Development (WCED). Report of the World Commission on Environment and Development: Our Common Future. 1987. Available online: https://sustainabledevelopment.un.org/content/documents/5987our-common-future.pdf (accessed on 30 August 2019).

2. UNEP. Towards a Green Economy: Pathways to Sustainable Development and Poverty Eradication-A Synthesis for Policy Makers. 2011. Available online: www.https://sustainabledevelopment.un.org/content/ documents/126GER_synthesis_en.pdf (accessed on 30 August 2019).

3. Pearce, D.; Barbier, M. Blueprint for a Green Economy; Earth Scan Publication: London, UK, 1989.

4. Bing, T.; Li, M. Does CSR signal the firm value? Evidence from China. Sustainability 2019, 11, 4255. [CrossRef]

5. Qiu, M.; Yin, H. An analysis of enterprises' financing cost with ESG performance under the background of ecological civilization construction. J. Quant. Tech. Econ. 2019, 36, 108123.

6. Huber, B.; Comstock, M.; Polk, D. ESG reports and ratings: What they are, why they matter. Harv. Law Sch. Forum Corp. Gov. Financ. Regul. 2017. Available online: https://corpgov.law.harvard.edu/2017/07/27/esgreports-and-ratings-what-they-are-why-they-matter (accessed on 30 August 2019).

7. Frooman, J. Socially irresponsible and illegal behavior and shareholder wealth: A meta-analysis of event studies. Bus. Soc. 1997, 36, 221-249. [CrossRef]

8. Schuler, D.; Cording, M. A corporate social performance-corporate financial performance behavioral model for consumers. Acad. Manag. Rev. 2006, 31, 540-558. [CrossRef] 
9. Eccles, R.; Serafeim, G.; Krzus, M. Market interest in nonfinancial information. J. Appl. Corp. Financ. 2011, 23, 113-127. [CrossRef]

10. Lantos, G. The boundaries of strategic corporate social responsibility. J. Consum. Mark. 2001, 18, 595-632. [CrossRef]

11. Zhu, Q.; Yin, H.; Liu, J.; Lai, K. How is employee perception of organizational efforts in corporate social responsibility related to their satisfaction and loyalty towards developing harmonious society in Chinese enterprises? Corp. Soc. Responsib. Environ. Manag. 2014, 21, 28-40. [CrossRef]

12. Guerrero, V.; Sierra, G.; Palacios, F. The role of sustainable development and innovation on firm performance. Corp. Soc. Responsib. Environ. Manag. 2018, 25, 1350-1362. [CrossRef]

13. Kriström, B.; Lundgren, T. Abatement investments and green goodwill. Appl. Econ. 2003, 35, $1915-1921$. [CrossRef]

14. Rivera, C. Re-evaluating green marketing strategy: A stakeholder perspective. Eur. J. Mark. 2007, 41, 1328-1358. [CrossRef]

15. Kushwaha, G.; Sharma, N. Green initiatives: A step towards sustainable development and firm's performance in the automobile industry. J. Clean. Prod. 2016, 121, 116-129. [CrossRef]

16. Kocmanová, A.; Dočekalová, M. Construction of the economic indicators of performance in relation to environmental, social and corporate governance (ESG) factors. Acta Univ. Agric. Silvicult. Mendel. Brun. 2013, 60, 195-206. [CrossRef]

17. Henriksson, R.; Livnat, J.; Pfeifer, P.; Stumpp, M. Integrating ESG in portfolio construction. J. Portf. Manag. 2019, 45, 67-81. [CrossRef]

18. Cheng, B.; Ioannou, I.; Serafeim, G. Corporate social responsibility and access to finance. Strat. Manag. J. 2014, 35, 1-23. [CrossRef]

19. Dimson, E.; Karakaş, O.; Li, X. Active ownership. Rev. Financ. Stud. 2015, 28, 3225-3268. [CrossRef]

20. El Ghoul, S.; Guedhami, O.; Kim, Y. Country-level Institutions, firm value, and the role of corporate social responsibility initiatives. J. Int. Bus. Stud. 2017, 48, 360-385. [CrossRef]

21. Revelli, C.; Viviani, J. Financial performance of socially responsible investing (SRI): What have we learned? A meta-analysis. Bus. Ethics Eur. Rev. 2015, 24, 158-185. [CrossRef]

22. Rowley, T.; Berman, S. A brand-new brand of corporate social performance. Bus. Soc. 2000, 39, $397-418$. [CrossRef]

23. Weber, O. Environmental, social and governance reporting in China. Bus. Strateg. Environ. 2014, $23,303-317$. [CrossRef]

24. Climent, F.; Soriano, P. Green and good? The investment performance of US environmental mutual funds. J. Bus. Ethics 2011, 103, 275-287. [CrossRef]

25. Silva, F.; Cortez, M. The performance of US and European green funds in different market conditions. J. Clean. Prod. 2016, 135, 558-566. [CrossRef]

26. Heckman, J. Micro data, heterogeneity, and the evaluation of public policy: Nobel lecture. J. Polit. Econ. 2001, 109, 673-748. [CrossRef]

27. Demidova, S.; Krishna, K. Firm heterogeneity and firm behavior with conditional policies. Econ. Lett. 2008, 98, 122-128. [CrossRef]

28. Kaplan, G.; Violante, G. Microeconomic heterogeneity and macroeconomic shocks. J. Econ. Perspect. 2018, 32, 167-194. [CrossRef]

29. Ramsey, F.; Schafer, D. The Statistical Sleuth: A Course in Methods of Data Analysis, 2nd ed.; Duxbury Press: Pacific Grove, CA, USA, 2002.

30. Hansen, L. A method for calculating bounds on the asymptotic covariance matrices of generalized method of moments estimators. J. Econ. 1985, 30, 203-238. [CrossRef]

31. Newey, W.; Windmeijer, F. Generalized method of moments with many weak moment conditions. Econometrica 2009, 77, 687-719.

32. Sardo, F.; Serrasqueiro, Z. A European empirical study of the relationship between firms' intellectual capital, financial performance and market value. J. Intel. Cap. 2017, 18, 771-788. [CrossRef]

33. Zhang, Y.; Qiao, Y.; He, X. Experience and empirical analysis of M\&A performance of listed companies in China. Res. Financ. Econ. Issues 2015, 1, 60-66.

34. Ge, J. An empirical study on method of payment and efficiency of merger and acquisition-Evidence of taking listed company as a target in China. Acc. Res. 2015, 9, 74-80. 
35. Jensen, M.; Ruback, R. The market for corporate control: The scientific evidence. J. Financ. Econ. 1983, 11, 5-50. [CrossRef]

36. Porter, M. From competitive advantage to corporate strategy. Harv. Bus. Rev. 1987, 65, 43-59.

37. Singh, H.; Montgomery, C. Corporate acquisition strategies and economic performance. Strateg. Manag. J. 1987, 8, 377-386. [CrossRef]

38. Li, S.; Zeng, Z. Characteristics of takeover targets in China equity market. Econ. Res. J. 2003, 11, 54-64.

39. Tang, J.; He, H. An empirical analysis of the synergies of M\&A in Chinese listed companies. Econ. Rev. 2005, 5, 93-100.

40. Gilson, R.; Black, B. The Law and Finance of Corporate Acquisitions; Foundation Press: Westbury, NY, USA, 1995.

41. Patell, J. Corporate forecasts of earnings per share and stock price behavior: Empirical test. J. Acc. Res. 1976, 14, 246-276. [CrossRef]

42. Almeida, H.; Fos, V.; Kronlund, M. The real effects of share repurchases. J. Financ. Econ. 2016, 119, $168-185$. [CrossRef]

43. Jarva, H.; Kallunki, J.; Livne, G. Earnings performance measures and CEO turnover: Street versus GAAP earnings. J. Corp. Financ. 2019, 56, 249-266. [CrossRef]

44. WIND Dataset. Available online: https://www.wind.com.cn/en/edb.html (accessed on 30 August 2019).

45. SynTao Green Finance. Landsea ESG Development Index. 2018. Available online: http://www.syntaogf.com/ Menu_EN.asp?ID=42 (accessed on 30 August 2019).

46. China Alliance of Social Value Investment. Sustainable Development Assessment Report. 2018. Available online: https://www.casvi.org/h-col-147.html (accessed on 30 August 2019).

47. Fuzi, S.; Halim, S.; Julizaerma, M. Board independence and firm performance. Procedia Econ. Financ. 2016, 37, 460-465. [CrossRef]

48. Lim, C.; Wang, J.; Zeng, C. China's "Mercantilist" Government subsidies, the cost of debt and firm performance. J. Bank. Financ. 2018, 86, 37-52. [CrossRef]

49. Newton, A. Executive compensation, organizational performance, and governance quality in the absence of owners. J. Corp. Financ. 2015, 30, 195-222. [CrossRef]

50. Lin, Y.; Li, Z. Policy burden, moral hazard and soft budget constraint. Econ. Res. J. 2004, 2, 17-27.

51. Huang, Y. Understanding China's belt \& road initiative: Motivation, framework and assessment. Chin. Econ. Rev. 2016, 40, 314-321. 